\title{
Does Sweden have room for its wolves?
}

Stephen Mills

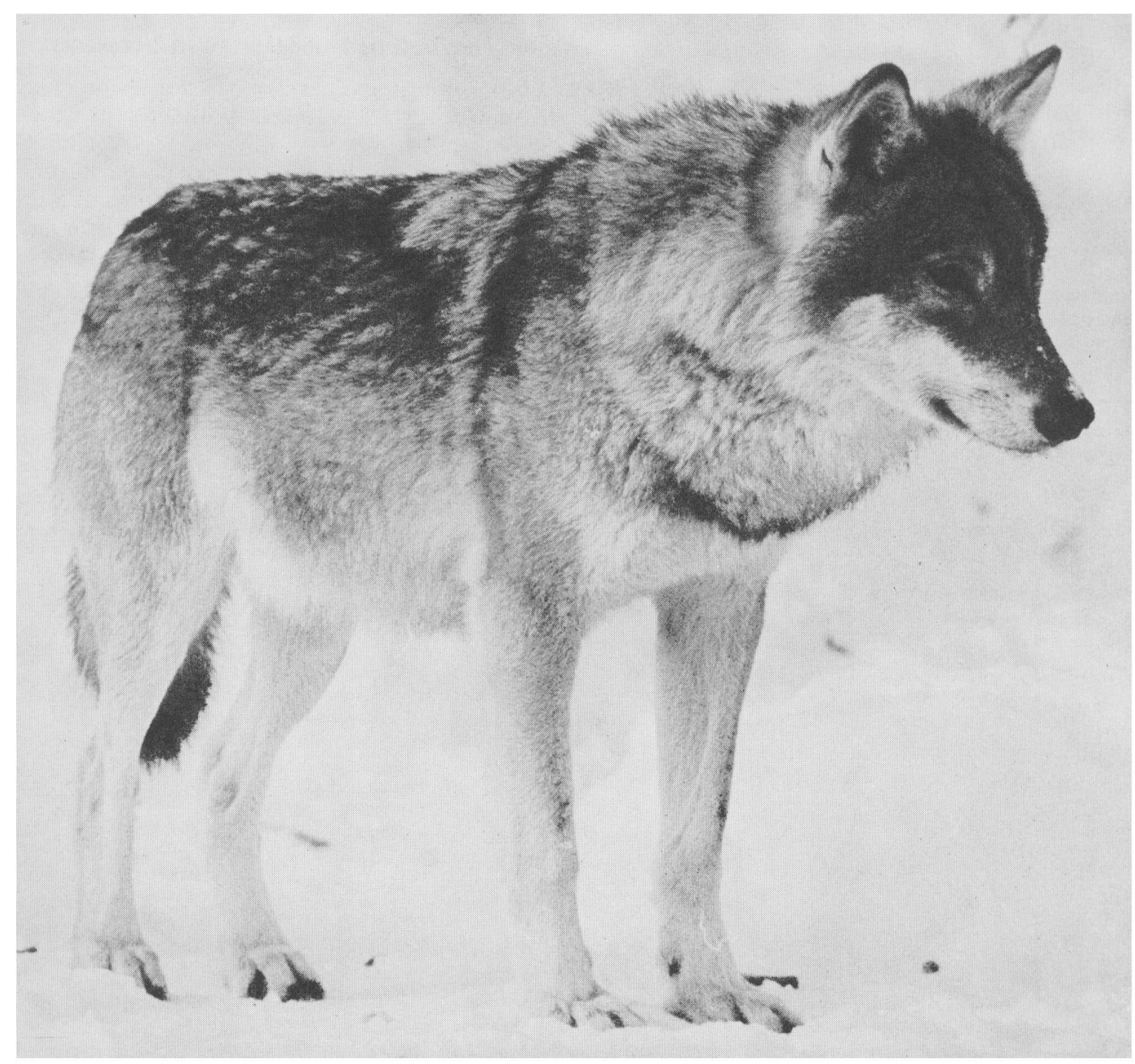


Just before Christmas 1985 wolf researchers in Sweden made a particularly ugly discovery: the ritually mutilated corpse of an 18-month-old pup. It had been shot and scalped, its ears removed and a hind leg cut off. Then, in February 1986, another young wolf was chased along a forest track by a car, which smashed its back legs and killed it. These are merely the latest incidents in an irrational anti-wolf campaign, which is threatening the species's tentative come-back in Scandinavia. The author, who has worked extensively with Scandinavian conservationists since 1971, describes the plight of Sweden's wolves and explains why it is important to protect them.

Wolves have been on the verge of extinction in Scandinavia since the 1920s. Outside Finland, where numbers were estimated at between 35 and 40 in 1978 (Ovesen et al., 1978), the total recorded population now numbers six individuals. All are in southern Sweden where they recently astonished everyone by breeding for three years in succession.

Until 1983, reproduction had been very irregular and always up in the high Arctic. Although a den was located there, in Swedish Lapland, in 1964, it took 14 years before the next one was found, by Dr Anders Bjärvall of the Swedish Environmental Protection Board, in 1978. He began tracking wolves in the region in 1977 and at one stage he knew of 14 animals (A. Bjärvall, pers. comm.). But wolves do not last long in Lapland, where the traditional reindeer herders are a law unto themselves, and by 1980 they had all disappeared.

In the winter of 1981, however, Bjärvall and his assistant, Erik Isakson, picked up the trail of a large male 800 miles to the south, circling the wooded county of Värmland. In 1982 they tracked a female into the area-sooner or later a female betrays herself in the snow by spots of menstrual blood in her urine marks-and in the spring of 1983 the two wolves mated and produced six pups. In 1984 they had two more young, and in 1985 they did it again, bearing no fewer than seven pups. This in itself was a sensation-for wolves in Sweden or Norway to breed twice, let alone three years in a row below the Arctic Circle was simply unknown in the twentieth century. For it to happen just two hours' drive from the Norwegian capital, Oslo, was unthinkable.

The result has been wolf hysteria, a blend of excitement and terror, sustained often unscrupulously by the media, which has swept both Sweden and Norway and which has ensured the deaths of most of the wolves. It is a phenomenon that may hold lessons for conservationists elsewhere.

\section{Destruction of the wolves in Sweden}

At first, things looked hopeful for the wolves (Wabakken et al., 1982). Värmland provides ideal, taiga-like habitat-6000 sq miles $(15,500$ sq $\mathrm{km}$ ) of rolling hillsides, wooded with spruce and birch, pitted with bogs and punctuated by long narrow lakes offering perfect hunting corridors in the frozen winters. It is relatively undisturbed since many younger people have moved closer to the towns, and, thanks in part

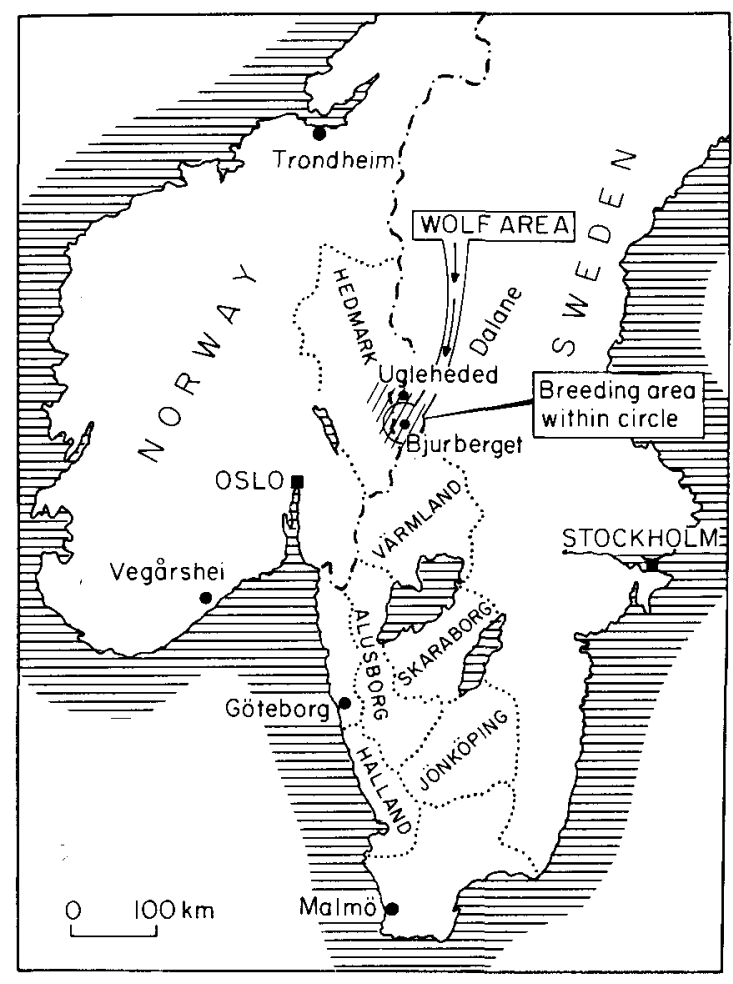

Map showing location of Sweden's wolves. 


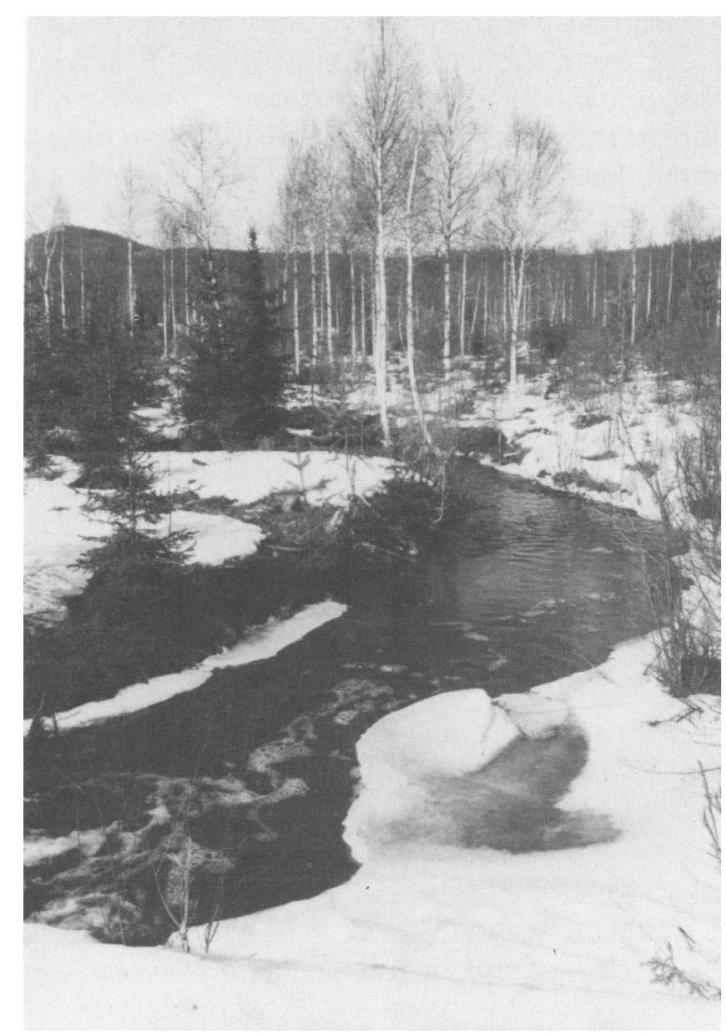

Spring in a Värmland forest (Stephen Mills).

to successful conservation measures, it holds denser populations of the wolf's favourite food, moose and roe deer, than anywhere in Scandinavia.

In 1984, however, the previous year's six pups began to scatter. Young wolves, especially males, often leave the pack and wander, though not usually until they are nearer two years old. Of these, only one, a female, stayed with the parents. Another female travelled 150 miles $(240 \mathrm{~km})$ north, where she vanished a year later, while the rest, probably all males, unchecked by the possibility of encountering any other wolves, covered thousands of miles between them before they were all, illegally, destroyed.

One was hit by a car on the outskirts of Stockholm and shot. One was shot north of the capital, while another reached Trondheim in 94 northern Norway before being dispatched. But it was the last pup that had the best documented odyssey. He travelled down village streets, past courting couples, through large towns, right the way to Malmö on the southern tip of Sweden. There he was captured by police, transported 100 miles $(160 \mathrm{~km})$ north of Värmland and released with a radio collar to be tracked by Bjärvall. Within weeks the transmitter had been smashed by a bullet and the pup, after being wounded by several different farmers, was killed in a field back down near Göteborg.

A Society for the Destruction of the Wolf was then formed, and because, for the past two years, the wolves have stayed close to their home range, its members have headed each autumn for Värmland to hunt the wolves there and to lay out meat laced with arsenic for them. At the end of July 1985 the mother wolf was shot, less than a mile from her den. During the following October and November three of that year's pups were shot nearby. No one was prosecuted. Altogether, nine of the 15 pups born have been killed illegally.

Sweden has ratified the Bern Convention and the wolf has been protected there since 1968. But the reality of having a large carnivore where it is least expected seems to have unleashed mythical fears, which make the protection laws difficult to apply.

\section{Wolf fever in Norway}

In Norway, wolf fever began even earlier. Two examples must suffice. In 1982 a male wolf, not one of the Värmland animals, appeared near Vegårshei, a village in the rocky county of Agder, $150 \mathrm{~km}$ south-west of Oslo. Adger is an important livestock area and the wolf was accused of killing sheep. Within months, the Royal Resolution of 1973, which afforded full protection to wolves (they were assumed to be extinct at the time), was amended so the Vegårshei animal could be shot. Conservationists pressed for one condition: that a 'viable' population of wolves must exist in Norway before hunting began. This was granted, but the authorities - the Norwegian Fish and Wildlife Directorate based in Trondheim-announced Oryx Vol 21 No 2. April 1987 
that Norway actually had 18 wolves and the population was increasing. The conservationists were furious since the Directorate's own research indicated that the Vegarshei wolf was the only one in Norway!

The issue had to be decided at Cabinet level where, despite the law, the death sentence was upheld and a $£ 2000$ bounty was placed on the wolf's head. On 11 January 1984 it was shot. The unofficial hunt leader, Lars Saga, had himself photographed pouring champagne over the corpse in his sitting-room. He then drove it to the parliament steps in Oslo where Agder MPs 'interviewed' it for TV and radio as part of a media extravaganza that lasted for three days (Mills, 1984).

For the next year, Norwegians, like the Swedes, kept on seeing 'wolves' and claiming compensation for savaged sheep, so in March 1985 zoologist Petter Wabakken organized a search. He put 500 people on skis to look for tracks along 1400 miles $(2200 \mathrm{~km})$ of prime terrain in Hedmark, the county that borders Sweden and Värmland, and from where many of the 'sightings' derived. They found nothing. But even though it was increasingly accepted that Norway had, for the moment anyway, shot its last wolf, the media would not relent. For newspapers and television had discovered a vested interest in keeping fear of the wolf alive. On the day they reported Wabakken's findings, Norwegian TV also showed faked footage of wolves intercut with shots of Hedmark schoolchildren 'fleeing for their lives'.

\section{The need for a rational management policy}

There has never been any question of the wolves attacking people in Scandinavia. They certainly have killed sheep-Bjärvall's radio-tagged animal was caught 'red-muzzled' at one point. But the likely impact on agricultural interests, even of a larger stable wolf population, is negligible. Norway, for instance, puts 2.3 million sheep out to pasture each summer (1984 figures). They are left to fend for themselves, and $80,000-100,000$ are lost annually. Of these, less than 5 per cent are killed by all the large

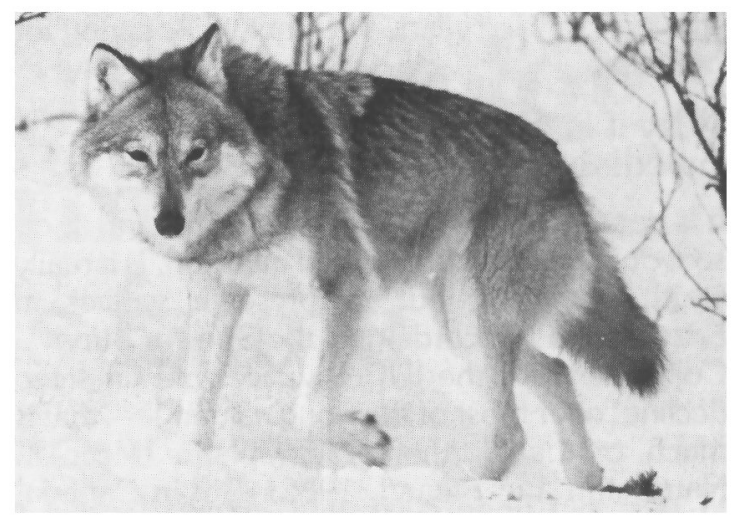

Adult female wolf in captivity (Vigo Ree).

predators-bears, wolverines, lynxes, eagles and 'wolves'-put together. The rest die of disease, fall over cliffs and into bogs, are harried by stray dogs or are stolen. In other words, careless husbandry is the problem, not wolves.

The Government pays compensation for livestock killed by predators. Suspected wolf kills account for about 6 per cent of the bill. Hunting down one wolf at Vegarshei cost three times as much as the total annual bill for all predators.

Why were these points not made clear to the public immediately? The answer is that the Swedish and Norwegian governments were unprepared for the 'crisis' and lacked a contingency plan. They were unsure of their commitment to the wolf when the 'protected' animal resurrected itself, and they allowed their laws and statistics to be bent. Perhaps their biggest mistake was to let non-government personnel hunt the wolves. The barbarous display, for example, of the dead Vegarshei animal, which the Norwegian authorities did not discourage, was precisely the sort of incident to keep irrational fears on the boil.

The wolf story emphasizes the fact that law without policy is useless. 'Policy' would have been an effective zoning system, allowing wolves to be removed from major livestock areas and, of course, from towns, but ensuring their total protection within, and along corridors between, prime wolf territories. It is worth noting that six of the wolves have been slaughtered within their home range in Värmland. It was particularly unforgivable that the mother wolf, which had not 
strayed for three years, was shot while caring for her pups.

\section{Why it is important to save the Swedish wolves?}

It is not too late to institute 'policy', though to do so would pose a fundamental question. Is it really worth going all out to preserve wolves in Scandinavia? According to the Species Survival Commission of the IUCN, wolves are in steep decline' over most of their original range - that is much of the Northern Hemisphere (Mech in Harrington and Paquet, 1982). But in Canada, Alaska, Minnesota, Yugoslavia and the USSR wolf populations are truly 'viable', so it might seem more important to save the species there rather than in Sweden and Norway. Furthermore, the Finnish zoologist Erkki Pulliainen has recently recorded a 14-fold increase in the number of wolves crossing into Finland from Soviet Karelia (Pulliainen in Harrington and Paquet, 1982), which raises the possibility that the Värmland animals are of Russian stock and not really 'Scandinavian' at all.

Nevertheless, I believe it is important to protect this particular wolf pack, for two reasons. Firstly, Norway and Sweden have an international responsibility. They are privileged nations, with small, wealthy populations inhabiting a disproportionately large slice of the world. They have to set a good example. It should not be forgotten that Norwegians sent $£ 7500$ to India to help conserve tigers, and tigers eat Indians and not just sheep. Sweden and Norway have also sent strongly worded petitions to stop the slaughter of small birds in Italy, a country that is managing to get along with 100 wolves.

Secondly, there is the local issue. Although it is essential to develop and maintain a world strategy for species conservation, that strategy is, itself, ultimately composed of thousands of interconnected 'local issues'. Failure to protect wolves in Scandinavia will have a knock-on effect there. The security enjoyed by predators is extremely tenuous. Rather like financial confidence in the city, the balance of opinion can easily be upset. If people see that wolves are not protected, even though they are rare, because they sometimes eat sheep, they will challenge conservationist values. What about goshawks 96 that eat chickens, and otters that eat fish? What about bears and eagles and wolverines and ospreys? Why conserve anything? In fact, there is evidence to suggest that this sort of slide in conviction did occur in Norway, since several permits for killing bears and wolverines were granted during the Vegårshei wolf affair.

\section{Will the pack survive?}

The death of the mother wolf has reduced the Värmland pack's chances of survival. Wolves, like humans, are selective about their mates (Mech, 1970). The old male, even though he holds the territory, may not wish to mate again. And it is even possible that he is the only male left-at least three of the other five wolves are definitely female and 1986 was almost certainly a blank year. But there is one hopeful sign: the young female remaining from the first litter has already assumed some of the roles of mate, for she took over the rearing of the orphaned pups of 1985 .

\section{Acknowledgments}

The author wishes to thank Dr Anders Bjärvall, Petter Wabakken, Viggo Ree and Erik Isakson for generous access to their research, for their continuous supply of information, and for their hospitality during trips to what ought to be the wolf zones; he also thanks Dr Patricia Phillips for much help in the UK.

\section{References}

Harrington, F.H. and Paquet, P.C. Ed. 1982. Wolves of the World. Noyes Co., Park Ridge, New Jersey.

Mech, L.D. 1970. The Wolf. Natural History Press, Garden City, New York.

Mills, S.P. 1984. The Big Bad Wolf? New Scientist, 104 (1432), 28-31

Ovesen, C.H., Norderhaug, M., Haapanen, A. and Zettersten, G. Ed. 1978. Hotade Djur och Växter i Norden. Nordiska Ministerrådet, Stockholm.

Wabakken, P., Sorensen, O.J. and Kvam, T. 1982. Wolves (Canis lupus) in Southeastern Norway. Lecture at the Third Theriological Congress, Fifth Intemational Wolf Symposium, 17 August. Helsinki.

Stephen Mills, Church Cottages, Forest Hill, Oxford OX9 $1 E D, U K$.

\section{Postscript}

The man who chased and killed a wolf with his car in spring 1986 has been caught and sentenced to four months' imprisonment. He is appealing.

Oryx Vol 21 No 2, April 1987 